\title{
PENERAPAN PENDEKATAN CONTEXTUAL TEACHING AND LEARNING (CTL) UNTUK MENINGKATKAN KEMAMPUAN MENULIS ARGUMENTASI MAHASISWA CALON GURU
}

\author{
Mastiah $^{1}$, M. Akip ${ }^{2}$, Sukristin ${ }^{3}$ \\ ${ }^{123}$ Program Studi Pendidikan Guru Sekolah Dasar, STKIP Melawi \\ Corresponding Email: mastiah2011@gmail.com
}

Received: $11^{\text {th }}$ of February 2020, Accepted: $6^{\text {th }}$ of May 2020, Published: $23^{\text {rd }}$ June 2020

\begin{abstract}
Abstrak
Tujuan dari penelitian ini adalah untuk meningkatkan kemampuan menulis argumentasi siswa STKIP Melawi. Metode yang digunakan dalam penelitian ini adalah metode kuasi eksperimen dengan desain nonequivalent control group. Hasil penelitian ini adalah 1) pretest rata-rata kemampuan argumentasi siswa kelas kontrol adalah 54,94, posttes 57,20, sedangkan kelas eksperimen mendapat nilai rata-rata pretest 51,44 , dan posttes 80,$04 ; 2$ ) Tidak ada perbedaan yang signifikan dalam kemampuan menulis argumentasi pada tes pretest antara kelompok kontrol dan kelompok eksperimen, sedangkan pada posttest ada perbedaan yang signifikan dalam kemampuan menulis argumentasi antara kelompok kontrol dan kelompok eksperimen.
\end{abstract}

Kata kunci: kemampuan menulis argumentasi, metode eksperimen semu, desain nonequivalent control group, pretes, posttes.

\begin{abstract}
The purpose of this research was to improve the writing ability of argumentation of STKIP Melawi students. The method used in this research was quasi experimental method with nonequivalent control group design. The results of this study were 1) the average pretest of students' argumentation ability of control class was 54,94, while posttes 57,20, while experimental class got pretest average value 51,44 , and posttes 80,$04 ; 2)$ There was no significant difference in the ability to write argumentation on pretest tests between the control group and experimental group, whereas in the posttest there was a significant difference in the ability to write argumentation between the control group and the experimental group.
\end{abstract}

Keywords: the writing ability of argumentation, quasi experimental method, nonequivalent control group design, pretes, posttest

Copyright @ 2020 Mastiah, M. Akip, Sukristin

\section{PENDAHULUAN}

Menulis merupakan satu di antara empat keterampilan berbahasa yang harus dikuasai oleh mahasiswa. Melalui menulis, mahasiswa dapat menuangkan ide dan pikiran mereka baik dalam bentuk artikel, makalah atau lainnya. Oleh karena itu, mahasiswa dituntut memiliki kemampuan menulis yang baik, sehingga ide atau pendapat yang mereka tuliskan dapat dipahamani dan diyakini oleh pembaca.

Kenyataan di lapangan dalam perkuliahan keterampilan menulis, ditemukan bahwa kemampuan mahasiswa calon guru, dalam menulis karangan argumentasi masih rendah. Hal ini terlihat dari beberapa hasil tulisan karangan argumentasi mahasiswa, yaitu 1) belum ditemukan gagasan yang menarik dalam tulisan, 2) gagasan atau pendapat mahasiswa belum 
tampak dalam tulisan, 3) urutan tulisan tidak logis, 4) isi tulisan lebih banyak memuat pendapat ahli tanpa adanya sisntesis dari mahasiswa.

Berdasarkan paparan di atas, tentuanya perkuliahan keterampilan menulis karangan argumentasi harus diorentasikan pada kemampuan berpikir kritis mahasiswa. Mengingat di antara empat aspek keterampilan berbahasa, keterampilan menulis merupakan aspek yang paling sulit. Sebagaimana pernyataan yang dikemukakan oleh Nurgiantoro (dalam Fauziyah, 2016: 160) bahwa dibanding ketiga keterampilan berbahasa yang lain (membaca, mendengarkan, dan berbicara), keterampilan menulis lebih sulit dikuasai bahkan oleh penutur asli bahasa yang bersangkutan sekalipun. Hal ini disebabkan kemampuan menulis menuntut penguasaan unsur-unsur dari segi kebahasaan dan unsur di luar bahasa itu sendiri yang menjadi isi karangan. Agar menghasilkan karangan yang runtut dan padu, semua unsur, baik baik bahasa isi haruslah terjalin sedemikian rupa.

Berdasarkan paparan yang telah disampaikan sebelumnya, tulisan ini memaparkan hasil penelitian tentang penerapan pendekatan pembelajaran dalam menulis karangan argumentasi. Dalam hal ini tim peneliti menerapkan pendekatan contextual teaching and learning (ctl).

Karangan argumentasi memilik beberapa pengertian dari beberapa ahli. Dalman (2016:138) berpendapat bahwa argumentasi adalah karangan yang bertujuan meyakinkan atau membuktikan kepada pembaca agar menerima suatu kebenaran isi tulisan yang disampaikan penulis sehingga pembaca meyakini kebenaran itu. Di sisi lain Wagiran (2010:76) menyatakan bahwa paragraf argumentasi yaitu paragraf yang bersifat membujuk atau meyakinkan pembaca dengan cara memaparkan alasan-alasan, fakta-fakta, atau buktibukti suatu pendapat atau gagasan pemecahan sebuah masalah. Sejalan dengan pendapat tersebut, dalam sebuah artikel ilmiah Yulia A dkk. (2012:339) mengatakan bahwa argumentasi merupakan salah satu jenis tulisan yang berusaha mempengaruhi pendapat orang lain melalui fakta-fakta. Tulisan argumentasi berusaha meyakinkan pembaca terhadap kebenaran pendapat atau pernyataan penulis. Melalui tulisan argumentasi, pembaca diyakinkan dengan pembuktian yang tepat dan benar dari bukti-bukti yang relevan dengan fakta.

Dari pengertian di atas peneliti menyimpulkan bahwa karangan argumentatif adalah karangan yang dituliskan dari gagasan untuk membuktikan suatu kebenaran dengan fakta dan bukti yang ada untuk meyakinkan pembaca dan menyetujui pendapat tersebut. 
Sama seperti menulis yang membutuhkan tahapan atau langkah-langkah, menulis karangan argumentasi juga membutuhkan tahapan atau langkah-langkah. Langkah-langkah menulis karangan argumentasi yaitu (1) menentukan topik atau tema karangan, (2) menetapkan tujuan, (3) mengumpulkan data bukti atau fakta dari berbagai sumber, (4) membuat kerangka karangan, (5) mengembangkan karangan, dan (6) memperbaiki karangan (Dalman, 2016: 140).

Pendekatan ctl merupakan pendekatan pembelajaran yang memberdayakan si pembelajar, dalam hal ini mahasiswa (Panjaitan, 2018: 53). Oleh karena itu, pendekatan ini menuntut mahasiswa untuk aktif dalam proses pembelajaran. Pendekatan ini sudah berkembang di dunia pendidikan kita saat ini. Hasibuan (2014:2) mengatakan bahha ctl merupakan proses pembelajaran yang menyeluruh dan bertujuan agar pembelajar dapat memahami makna materi ajar dan mengaitkannya dengan konteks kehidupan mereka sehari-hari, baik dalam kehidupan pribadi, keluarga, sosial dan kultural, sehingga pembelajar mempunyai pengetahuan/ keterampilan yang dinamis dan fleksibel untuk membangun sendiri secara aktif pemahamannya. Hal ini sejalan dengan pendapat Suprijono (2010:79-80), yaitu dia mengemukakan bahwa pembelajaran dengan pendekatan ctl merupakan konsep yang membantu pengajar (dosen atau guru) mengaitkan antara materi yang diajarkan dengan situasi nyata dan mendorong pembelajar membuat kaitan atau hubungan antara pengetahuan mereka dengan penerapannya dalam kehidupan mereka sebagai anggota keluarga dan masyarakat. Jadi, proses pembelajaran ctl beraksentuasi pada pemrosesan informasi, individualisasi, dan interaksi sosial. Lebih lanjut Pranowo (2014:2017) berpendapat bahwa pembelajaran dengan pendekatan ctl tidak hanya membuat pembelajar memahami konsepkonsep teoretis tetapi menjadikan pembelajar (a) mampu menerima tanggung jawab atas keputusan dan perilaku sendiri, (b) mampu menilai berbagai alternatif, (c) mampu membuat pilihan, (d) mampu mengembangkan rencana, (e) mampu menganalisis informasi, (f) mampu menciptakan solusi, dan (g) mampu menilai bukti-bukti secara kritis.

Dari paparan uraian di atas peneliti menyimpulkan bahwa pendekatan ctl merupakan suatu pendekatan yang digunakan dalam proses pembelajaran untuk membelajarkan materi dengan mengaitkan situasi nyata dengan kehidupan peserta didik dalam bermasyarakat untuk memperoleh informasi dan memecahkan masalah.

\section{METODE}

Penelitian ini dilaksanakan dengan menggunakan metode kuasi eksperimen dengan pendekatan kuantitatif untuk memperoleh gambaran tentang proses pembelajaran. Pada 
pelaksanaannya, penelitian ini dibentuk ke dalam dua kelompok, kelompok tersebut yaitu kelompok kontrol dan kelompok eksperimen. Kelompok eksperimen dilakukan pada subjek penelitian dengan menggunakan pendekatan kontekstual dalam pembelajaran menulis teks argumentasi. Sedangkan untuk kelompok kontrol menggunakan metode konvensional yaitu ceramah dan penugasan. Sekalipun berbeda namun kedua kelompok ini sama-sama diberikan tes awal atau pretes dan tes akhir atau posttes. Tes ini berupa instrumen tes menulis teks argumentasi yang sama.

\section{Variabel Penelitian}

Penelitian ini terdiri atas tiga variabel, yaitu satu variabel bebas dan dua variabel terikat. Variabel bebas dalam penelitian ini adalah pendekatan kontekstual, sedangkan variabel terikatnya dalah kemampuan menulis argumentasi dan berpikir kritis.

\section{Lokasi dan Waktu Penelitian}

Lokasi penelitian dilaksanakan di STKIP Melawi, tepatnya kelas A dan B semester II Program Studi PGSD (Pendidikan Guru Sekolah Dasar) yang berlokasi di Jl. RSUD Melawi Km. 04 Kecamatan Nanga Pinoh Kabupaten Melawi. Penelitian ini dilaksanakan pada semester genap tahun akademik 2016/2017.

\section{Populasi dan Sampel}

Populasi dalam penelitian ini adalah mahasiswa calon guru sekolah dasar yaitu mahasiswa PGSD STKIP Melawi. Penentuan sampel dilakukan dengan teknik sampling purposive, teknik ini dipilih karena ada pertimbangan tertentu (Sugiyoono, 2017: 124). Yaitu, mahasiswa yang menjadi sampel dalam penelitian ini adalah mahasiswa semester II kelas A dan B. Sampel dipilih karena memperoleh mata kuliah Keterampilan Menulis pada tahun 2016/2017. Dari kedua kelas tersebut yang menjadi kelas eksperimen adalah kelas B sedangkan yang menjadi kelas kontrol adalah kelas A.

\section{Prosedur Penelitian}

Prosedur penelitian ini didesain dengan menggunakan penelitian kuasi eksperimen dengan model desain nonequivalent control group design. Desain ini dipiih karena peneliti menggunakan kelas-kelas yang sudah ada. Model desain dari nonequivalent control group design.

\section{Teknik Pengumpulan Data dan Instrumen Penelitian}

Pengumpulan data dalam penelitian ini adalah dengan cara tes menulis argumentasi. Tes ini dilakukan untuk mengumpulkan data kemampuan mahasiswa dalam menulis karangan argumentasi sebelum dan sesudah dilakukan perlakuan. 
Instrumen yang digunakan dalam penelitian ini adalah rubrik penilaian tes kemampuan menulis argumentasi.

Rubrik penilaian tes ini disusun dan digunakan untuk mengetahui sejauh mana kemampuan mahasiswa dalam menulis argumentasi. Rubrik penilaian tes ini digunakan untuk menilai hasil pretes dan postes pada kelas eksperimen dan kelas kontrol. Penilaian hasil pretes bertujuan untuk melihat atau mengetahui kemampuan mahasiswa menulis argumentasi sebelum mereka diberikan perlakuan, sedangkan postes untuk mengetahui kemampuan mahasiswa dalam menulis argumentasi, yaitu setelah mahasiswa diberi perlakuan berupa pendekatan ctl di kelas eksperimen dan pendekatan konvensional di kelas kontrol.

\section{Validitas dan Reliabilitas Instrumen}

Validitas perlu dilakukan untuk mengetahui kelayakan instrumen. Validitas ini dilakukan setelah penyusunan instrumen selesai. Hal ini dilakukan untuk dapat mengukur kualitas instrumen dan menghasilkan data yang akurat. Selanjutnya, instrument tersebut dilakukan penimbangan (judgment) oleh ahli yaitu dosen lainnya terlebih dahulu agar intrumen layak digunakan dalam pelaksanaan penelitan.

Reliabilitas perlu dilakukan untuk mengetahui keterandalan instrumen (Arikunto, 2014: 221). Maksudnya suatu instrumen dikatakan reliabel jika instrumen tersebut sudah baik dan dapat dipercaya untuk mengumpulkan data. Untuk uji reliabilitas, instrumen yang telah divalidasi diujicobakan pada kelas dan mahasiswa yan berbeda, setelah itu dicari reliabilitas instrumen dengan rumus alpha.

\section{Teknik Analisis Data}

Teknik analisis ini merupakan penjabaran peneliti menganalisis data yang didapatkan dari hasil penelitian di lapangan. Data tersebut diperoleh melalui hasil tes kemudian dianalisis.

Analisis deskriptif

Analisis ini dilakukan untuk mendeskripsikan data penelitian ini yang berupa skor hasil penilaian pretes dan postes kemampuan menulis argumentasi mahasiswa. Pada penelitian ini analisis data yang digunakan rumus rata-rata (mean), sebagai berikut:

$$
M e=\frac{\sum x i}{n}
$$

Keterangan:

$$
\begin{aligned}
& \boldsymbol{M} \boldsymbol{e}=\text { Mean (Rata-Rata) } \\
& \sum=\text { Epsilon (Jumlah) }
\end{aligned}
$$


$\boldsymbol{x} \boldsymbol{i}=$ Nilai $\mathrm{x}$ ke i sampai ke $\mathrm{n}$

$\boldsymbol{n}=$ Jumlah Individu

(Sugiyono, 2011: 49)

Uji normalitas

Uji normalistas dilakukan untuk mengetahui apakah data kemampuan menulis argumentasis kelas eksperimen dan kelas kontrol berdistribusi normal atau tidak. Uji normalitas ini merupakan langkah awal dalam menganalisis data yang diolah. Uji normalitas dilakukan dengan memakai alat bantu SPSS dengan menggunakan uji Shapiro-Wilk.

Uji homogenitas

Jika semua data berdistribusi normal, langkah selanjutnya adalah uji homogenitas. Uji homogenitas varian data mahasiswa kelas eksperimen dan kelas kontrol dimaksudkan untuk mengetahui apakah varian data homogen atau tidak. Uji homogenitas varian data ini menggunakan uji statistik livene's test.

Uji hipotesis

Uji hipotesis digunakan untuk mengetahui perbedaan kemampuan menulis argumentasi mahasiswa kelas eksperimen dan kelas kontrol. Uji hipotesis ini dilakukan jika data berdistribusi normal dan homogen, maka dilanjutkan uji signifikansi dengan statistik uji t menggunakan uji statistik compare mean independent test untuk membandingkan perbedaan dan rata-rata. Apabila data berdistribusi tidak normal maka dipakai uji non parametrik yaitu dengan mann whitney- $u$.

\section{HASIL DAN PEMBAHASAN}

\section{Uji Validitas}

Penelitian ini menggunakan uji validitas isi yang ditentukan melalui pertimbangan ahli. Instrumen penelitian ini telah diuji oleh dua orang dosen STKIP Melawi, yaitu 1) Ason, M.Pd. (Jabatan fungsional: Lektor; Pengampu matakuliah: Psikologi pendidikan, Perkembangan Peserta Didik), dan 2) Septian Peterianus, S.S., M.Hum. (Jabatan fungsional: belum ada; Penulis buku. Pengampu matakuliah: Pendidikan Keterampilan Berbahasa, Bahasa Indonesia, Literasi Berbahasa).

Instrumen yang divalidasi adalah rubrik penilaian kemampuan menulis argumentasi. Pada tanggal 11 Mei 2017, instrumen tersebut telah divalidasi oleh para ahli. Penilaian kemampuan menulis argumentasi, Ason, M.Pd. memberi jumlah nilai sebesar 30 (tiga puluh), sedangkan Septian Peterianus, S.S., M.Pd. memberi jumlah nilai sebesar 38 (tiga puluh delapan). Dari penilaian uji validasi tersebut dapat disimpulkan bahwa instrumen penilaian 
kemampuan menulis argumentasi layak digunakan untuk pengumpulan data dalam penelitian karena masuk dalam rentang nilai (25-40) yaitu layak digunakan.

\section{Uji Reliabilitas}

Setelah instrumen divalidasi, instrumen tersebut diuji reliabilitasnya. Pada uji reliabilitas ini, instrumen diuji cobakan pada mahasiswa STKIP Melawi Kampus Wilayah Perbatasan Entikong kelas A Semester II Tahun Akademik 2016/2017 pada tanggal 19 Mei 2017. Selanjutnya hasil uji coba instrumen dicari reliabilitasnya menggunakan rumus cronbach's alpha. Hasil perhitungan reliabilitas instrumen kemampuan menulis argumentasi kemampuan menulis argumentasi sebesar 0,788372. Kemudian nilai tersebut dibandingkan dengan nilai rtabel, yaitu untuk $n=27$ nilai rtabel dengan signifikansi 5\% adalah 0,381.

Berdasarkan data tersebut dapat disimpulkan bahwa bahwa instrumen penilaian kemampuan menulis argumentasi reliabel, yaitu dengan nilai rhitung > rtabel yaitu $0,788372>0,381$.

\section{Analisis Deskriptif}

Analisis deskriptif digunakan untuk mendeskripsikan kemampuan menulis argumentasi dan kemampuan berpikir kritis mahasiswa calon guru kelas eksperimen dan kelas kontrol. Pada penelitian ini analisis data yang digunakan rumus rata-rata (mean). Berikut dipaparkan hasil analisis tersebut.

Pada sub ini akan dipaparkan kemampuan menulis argumentasi mahasiswa calon guru kelas eksperimen dan kontrol sebelum dan sesudah perlakuan. Kelas eksperimen diberi perlakuan dengan pendekatan ctl, sedangkan kelas kontrol tidak mendapatkan perlakuan atau tetap dengan pendekatan konvensional.

Data pretes kemampuan menulis argumentasi kelas kontrol pada penelitian ini memperoleh skor dengan angka terendah yaitu 38,89 dan angka tertinggi yaitu 72,22. Setelah itu, dilakukan posttes tanpa diberi perlakuan. Hasil posttes kemampuan menulis argumentasi kelas kontrol pada tabel 5.2 tersebut memperoleh skor dengan angka terendah yaitu 38,89 dan angka tertinggi yaitu 83,33.

Hasil dari perhitungan rata-rata skor pretest dan posttest kemampuan menulis argumentasi mahasiswa kelas kontrol, yaitu pretes memperoleh nilai rata-rata (mean) 54,94, sedangkan posttes memperoleh nilai rata-rata (mean) 57,20. Untuk lebih jelasnya dapat dilihat pada tabel berikut: 
Tabel 1. Rata-Rata Skor Pretest dan Posttest Kemampuan Menulis Argumentasi

Kelas Kontrol

\begin{tabular}{cccc}
\hline Data & $\begin{array}{c}\text { Jumlah } \\
\text { Siswa }\end{array}$ & $\begin{array}{c}\text { Mean } \\
\text { (Nilai Rata-Rata) }\end{array}$ & $\begin{array}{c}\text { Selisih } \\
\text { Rata-Rata }\end{array}$ \\
\cline { 1 - 3 } Pretest & 27 & 54,94 & 2.26 \\
\cline { 1 - 3 } Posttest & 27 & 57,20 & \\
\hline
\end{tabular}

Berdasarkan dari analisis rata-rata hasil pretest dan rata-rata hasil posttest kemampuan menulis argumentasi mahasiswa kelas kontrol terdapat perbedaan (selisih) rata-rata yaitu sebesar 2,26.

Data pretes kemampuan menulis argumentasi kelas eksperimen sebelum diberi perlakuan dengan pendekatan ctl pada penelitian ini memperoleh skor dengan angka terendah yaitu 38,89 dan angka tertinggi yaitu 66,67. Setelah itu, diberi perlakuan dengan pendekatan ctl. Selanjutnya dilakukan posttes. Hasil posttes kemampuan menulis argumentasi kelas eksperimen pada tabel 5.3 tersebut memperoleh skor dengan angka terendah yaitu 50,00 dan angka tertinggi yaitu 100 .

Hasil dari perhitungan rata-rata skor pretest dan posttest kemampuan menulis argumentasi mahasiswa kelas eksperimen, yaitu pretes memperoleh nilai rata-rata (mean) 51,44, sedangkan posttes memperoleh nilai rata-rata (mean) 80,04. Untuk lebih jelasnya dapat dilihat pada tabel berikut:

Tabel 2. Rata-Rata Skor Pretest dan Posttest Kemampuan Menulis Argumentasi

Kelas Eksperimen

\begin{tabular}{cccc}
\hline Data & $\begin{array}{c}\text { Jumlah } \\
\text { Siswa }\end{array}$ & $\begin{array}{c}\text { Mean } \\
\text { (Nilai Rata-Rata) }\end{array}$ & $\begin{array}{c}\text { Selisih } \\
\text { Rata-Rata }\end{array}$ \\
\cline { 1 - 3 } Pretest & 27 & 51,44 & 28,60 \\
\cline { 1 - 3 } Posttest & 27 & 80,04 & \\
\hline
\end{tabular}

Berdasarkan dari analisis rata-rata hasil pretest dan rata-rata hasil posttest kemampuan menulis argumentasi mahasiswa kelas eksperimen terdapat perbedaan (selisih) rata-rata yan signifikan yaitu sebesar 28,60.

\section{Uji Normalitas Data}

Pengujian normalitas data kelas kontrol dan kelas eksperimen dilakukan untuk mengetahui data yang diperoleh berdistribusi normal atau tidak. Hal ini diperlukan sebagai uji prasyarat uji hipotesis. Pengujian normalitas data pada penelitian ini dilakukan dengan menggunakan program SPSS 17 dengan taraf signifikansi 0,05.

Hasil uji normalitas data tes awal (pretes) dan tes akhir (postes) kemampuan menulis argumentasi mahasiswa dapat dilihat pada tabel 3 dan tabel 4. 
Tabel 3. Normalitas Data Tes Awal (Pretes) Kemampuan Menulis Argumentasi

Kelas Kontrol dan Kelas Eksperimen

\begin{tabular}{lrrr}
\hline \multicolumn{1}{c}{ Pretes } & \multicolumn{3}{c}{ Shapiro-Wilk } \\
\cline { 2 - 4 } & Statistic & Df & Sig. \\
\hline Kelas_Kontrol & .909 & 27 & .022 \\
Kelas_Eksperimen & .940 & 27 & .122 \\
\hline
\end{tabular}

Berdasarkan hasil uji normalitas dengan uji shapiro-wilk pada tabel 3 tersebut, nilai signifikasi data tes awal (pretes) kemampuan menulis argumentasi kelas kontrol adalah 0,022 dan untuk kelas eksperimen adalah 0,122. Dari hasil tersebut dapat disimpulkan bahwa data tes awal (pretes) kemampuan menulis argumentasi kelas kontrol tidak berdistribusi normal karena lebih kecil dari 0,05, sedangkan kelas eksperimen berdistribusi normal karena lebih besar dari 0,05 .

Tabel 4. Normalitas Data Kemampuan Menulis Argumentasi (Postes)

\begin{tabular}{lrrr}
\hline \multicolumn{1}{c}{ Posttes } & \multicolumn{3}{c}{ Shapiro-Wilk } \\
\cline { 2 - 4 } & Statistic & Df & Sig. \\
\hline Kelas_Kontrol & .946 & 27 & .175 \\
Kelas_Eksperimen & .886 & 27 & .007 \\
\hline
\end{tabular}

Berdasarkan hasil uji normalitas dengan uji shapiro-wilk pada tabel 4 tersebut, nilai signifikasi data tes akhir (postes) kemampuan menulis argumentasi kelas kontrol adalah 0,175 dan untuk kelas eksperimen adalah 0,007. Dari hasil tersebut dapat disimpulkan bahwa data tes akhir (postes) kelas kontrol berdistribusi normal karena lebih besar dari 0,05, sedangkan kelas eksperimen tidak berdistribusi normal karena kurang dari 0,05.

Berdasarkan uji normalitas yang telah dipaparkan sebelumnya, tidak semua variabel berdistribusi normal. Oleh karena itu, selanjutnya uji hipotesis dilakukan dengan uji statistik nonparamatrik, yaitu uji Mann-Whitney $U$.

\section{Uji Hipotesis}

Uji hipotesis dalam penelitian ini dilakukan dengan menggunakan uji Mann-Whitney $U$. Hipotesis yan diajukan adalah:

$\mathrm{H}_{\mathrm{o}}: \mu_{1}=\mu_{2}$ (Tidak terdapat perbedaan rata-rata yang signifikan antara kelompok kontrol dan kelompok eksperimen)

$\mathrm{H}_{1}: \mu_{1} \neq \mu_{2} \quad$ (Terdapat perbedaan rata-rata yang signifikan antara kelompok kontrol dan kelompok eksperimen)

Kriteria pengujian adalah tolak $\mathrm{H}_{0}$ jika p-value (Sig.) $<\alpha=0,05$, sedangkan untuk kondisi lainnya $\mathrm{H}_{0}$ diterima. 
Tabel 5. Hasil Uji Hipotesis Kemampuan Menulis Argumentasi Mahasiswa

Kelas Kontrol dan Eksperimen

\section{Test Statistics ${ }^{\mathrm{a}}$}

Kemampuan_menulis_argu Kemampuan_menulis_argum mentasi_pretes entasi_postes

\begin{tabular}{lrr}
\hline Mann-Whitney U & 286.000 & 88.000 \\
Wilcoxon W & 664.000 & 466.000 \\
Z & -1.383 & -4.814
\end{tabular}

Asymp. Sig. (2-

tailed)

a. Grouping Variable: Faktor

Berdasarkan data pada tabel 5 tersebut dapat diketahui bahwa p value (sig.) pada pretes kemampuan menulis argumentasi kelas kontrol dan eksperimen sebesar 0,167. Ini berarti bahwa $\mathrm{p}$ value (sig.) $>\alpha$ atau 0,167 >0,05. Oleh karena itu, $\mathrm{H}_{0}$ diterima, sedangkan $\mathrm{H}_{1}$ ditolak. Artinya tidak terdapat perbedaan yang signifikan kemampuan menulis argumentasi pada tes awal (pretes) antara kelompok kontrol dan kelompok eksperimen.

Adapun hasil uji hipotesis posttes kemampuan menulis argumentasi mahasiswa kelas kontrol dan eksperimen $p$ value (sig.) sebesar 0,000 . Ini berarti bahwa p value (sig.) $<\alpha$ atau $0,000<0,05$. Oleh karena itu, $\mathrm{H}_{0}$ ditolak, sedangkan $\mathrm{H}_{1}$ diterima. Artinya terdapat perbedaan yang signifikan kemampuan menulis argumentasi pada tes akhir (postes) antara kelompok kontrol dan kelompok eksperimen. Berdasarkan hasil tersebut dapat disimpulkan bahwa pendekatan ctl memiliki pengaruh yan signifikan terhadap kemampuan menulis argumentasi mahasiswa.

Berdasarkan hasil penelitian yang telah dipaparkan sebelumnya, pendekatan ctl dapat meningkatkan kemampuan menulis argumentasi mahasiswa. Selain itu berdasarkan hasil uji hipotesis membuktikan bahwa pendekatan ctl memiliki pengaruh yang signifikan terhadap kemampuan menulis argumentasi mahasiswa. Artinya, dengan menerapkan pendekatan ctl, kemampuan mahasiswa meningkat dalam hal memaparkan alasan-alasan, fakta-fakta, atau bukti-bukti suatu pendapat atau gagasan pemecahan sebuah masalah dalam bentuk tulisan yaitu tulisan argumentasi sehingga dapat meyakinkan pembaca terhadap pendapat yang mereka tulis. Hal ini dapat memperkuat pendapat Pranowo (2014:2017) bahwa pembelajaran dengan pendekatan ctl menjadikan pembelajar mampu mengembangkan rencana, menganalisis informasi, menciptakan solusi, dan menilai bukti-bukti secara kritis. 


\section{SIMPULAN}

Kemampuan menulis argumentasi mahasiswa kelas kontrol, yaitu pretes memperoleh nilai rata-rata (mean) 54,94, sedangkan posttes memperoleh nilai rata-rata (mean) 57,20. Adapun kemampuan menulis argumentasi mahasiswa kelas eksperimen, yaitu pretes memperoleh nilai rata-rata (mean) 51,44, sedangkan posttes memperoleh nilai rata-rata (mean) 80,04.

Tidak terdapat perbedaan yang signifikan kemampuan menulis argumentasi pada tes awal (pretes) antara kelompok kontrol dan kelompok eksperimen, sedangkan pada tes akhir (posttes) terdapat perbedaan yang signifikan kemampuan menulis argumentasi antara kelompok kontrol dan kelompok eksperimen.

\section{REFERENSI}

Arikunto, S. (2014). Prosedur Penelitian. Jakarta: Rineka Cipta.

Dalman, H. (2016). Keterampilan Menulis. Jakarta: RajaGrafindo Persada.

Fauziya, D.S. (2016). Pembelajaran Kooperatif Melalui Teknik Duti-Duta dalam Meningkatkan Kemampuan Menulis Argumentasi. Riksa Bahasa: Jurnal Bahasa, Sastra, dan Pembelajarannya. (Online) Volume 2, No. 2. (https://ejournal.upi.edu/index.php/RBSPs, diakses 2 April 2020).

Hasibuan, M.I. (2014). Model Pembelajaran CTL (Contextual Teaching and Learning). Logaritma: Jurnal Ilmu-Ilmu Pendidikan dan Sains. (Online) Volume 2, No. 1. (http://jurnal.iain-padangsidimpuan.ac.id/index.php/LGR, diakses 4 April 2020).

Panjaitan, D.J. (2018). Peningkatan Pemahaman dan Aplikasi Konsep Melalui Pendekatan Contextual Teaching and Learning. Jurnal MathEducation Nusantara. (Online) Volume 1, No. 1. (https://jurnal.pascaumnaw.ac.id/index.php/JMN, diakses 2 April 2020).

Pranowo. (2014). Teori Belajar Bahasa: Untuk Gurun Bahasa dan Mahasiswa Jurusan Bahasa. Yogyakarta: Pustaka Pelajar.

Sugiyono. (2011). Metode Penelitian Kualitatif, Kuantitif, dan R\&D. Bandung: Alfabeta. Suprijono, A. (2010). Cooperative Learning Teori dan Aplikasi PAIKEM. Yogyakarta: Pustaka Pelajar

Wagiran. (2010). Silabus dan Handout Menulis Karya Ilmiah. Semarang: Universitas Negeri Semarang. 
Yulia A.D., Syahrul R., Ratna Ellya. (2012). Peningkatan Keterampilan Menulis Argumentasi Siswa Kelas X SMK N 1 Batusangkar dengan Pendekatan Kontekstual. Jurnal Pendidikan Bahasa dan Sastra Indonesia. (Online) Volume 1 No. 1. (https://www.neliti.com/publications, diakses tanggal 5 April 2020) . 